\title{
Earliest Silurian supra-subduction magmatism in central Cape Breton Island
}

\author{
J.D. Keppie' ${ }^{1}$ J. Dostal' , D.W. Davis ${ }^{3}$, and D.A. Horton ${ }^{2}$ \\ 'Instituto de Geologia, Universidad Nacional Autonoma de Mexico, 04510 Mexico D.F., Mexico \\ ${ }^{2}$ Department of Geology, Saint Mary's University, Halifax, Nova Scotia, B3H 3C3, Canada \\ ${ }^{3}$ Earth Science Department, Royal Ontario Museum, Toronto, Ontario, M5S 2C6, Canada
}

Date Received July 21, 1997

Dave Accepted April 15, 1998

\begin{abstract}
The Skye Mountain pluton intruded the Late Proterozoic Bras d'Or Gneiss in the Creignish Hills of central Cape Breton Island. It is composed of amphibole-bearing mafic rocks (gabbro and diorite) with quartz diorite occurring in the northern portion. U-Pb isotopic analyses of zircon give an age of $438 \pm 2 \mathrm{Ma}$, i.e., earliest Silurian. The rocks are calc-alkaline with mantle-normalized patterns characterized by high LILE/HFSE (large-ion-lithophile elements/highfield-strength elements) ratio and pronounced negative $\mathrm{Nb}$ anomalies. The pluton is inferred to have intruded a supra-subduction zone setting. As such, it represents a southern extension of an Early Silurian arc that extends along the axis of the Cape Breton Highlands. These calc-alkaline rocks contrast with contemporaneous, tholeiitic rift-related volcanism that occurs in the Antigonish Highlands. A possible tectonic setting that explains both these suites suggests that oblique, sinistral south-dipping subduction began north of Cape Breton Island and changed westwards into a sinistral transform boundary, which induced rifting in mainland Nova Scotia.

Le pluton du mont Skye fait intrusion dans le gneiss du protérozoïque tardif de Bras D'Or des collines Creignish, dans le centre de l'île du Cap-Breton. Il est constitué de roches mafiques amphibolifères (gabbro et diorite) accompagnées de diorite quartzique dans la partie septentrionale. Des analyses isotopiques au U-Pb du zircon le situent à $438 \pm 2 \mathrm{Ma}$, c.-à-d. à la fin du Silurien précoce. Les roches sont des roches calco-alcalines présentant des structures normalisées mantéliques caractérisées par un rapport élevé d'ELGI/EICE (éléments lithophiles à gros ions/éléments à intensité de champ élevée) et par des anomalies négatives de $\mathrm{Nb}$ prononcées. On suppose que le pluton fait intrusion dans le cadre d'une zone de supra-subduction. Il représente comme tel un prolongement méridional d'un arc du Silurien précoce qui s'étend le long de l'axe des hautes-terres du Cap-Breton. Ces roches calco-alcalines font contraste avec le volçanisme tholéiitique contemporain lié à une fracture qui est survenu dans les hautes-terres d'Antigonish. Une compaction tectonique possible expliquant ces deux cortèges laisse supposer que la subduction oblique sénestre inclinée vers le sud a commencé au nord de l'île du Cap-Breton et s'est transformée vers l'ouest en une marge de cisaillement sénestre qui a produit une distension continentale dans l'intérieur de la Nouvelle-Écosse.
\end{abstract}

[Traduit par la rédaction]

\section{INTRODUCTION}

The Late Ordovician and Early Silurian represent a critical time during the last stages of the closure of the Iapetus ocean. Magmatism forms an integral part of this geological record along the southeastern side of Iapetus in the Canadian Appalachians (Figs. 1, 2). Here, Early Silurian magmatism varies from calc-alkaline arc rocks in southern Newfoundland and the Cape Breton Highlands to tholeiitic rift-related rocks in the Antigonish and Cobequid Highlands (Keppie et al., 1979, 1992; Dunning et al., 1990a and b; Barr and Jamieson, 1991). This variation has been interpreted as an oblique subduction boundary in the northeast that became a sinistral transform boundary to the southwest (Keppie et al., 1992), however, other interpretations are possible. For example, the calc-alkaline-tholeiitic transition could represent a change from an arc to a backarc environment with interfingering of magmatic types at the boundary. Unfortunately, a gap in Early Silurian rocks occurs between the Cape Breton Highlands and the Antigonish Highlands. The Skye Mountain pluton lies in the middle of this gap thereby providing an important link between the two magmatic provinces.

\section{Geological Setting}

The Canadian Appalachians have been subdivided into a number of zones or terranes which record the passing of Iapetus (Fig. 1) (Williams, 1978; Williams and Hatcher, 1982; Keppie, 1985; Keppie et al., 1997): (1) Humber Zone marks the Laurentian margin of Iapetus; (2) Dunnage Zone (Notre Dame and Exploits terranes) preserves vestiges of Iapetus; (3) Gander Zone or Terrane is interpreted as the continental rise prism bordering the southeastern margin of Iapetus; (4) Avalon Zone or Composite Terrane represents a microcontinental block derived from the southeastern margin of Iapetus; and (5) the Meguma Zone or Terrane is inferred to be a continental rise prism deposited along the southeastern margin of the Avalon microcontinent. 


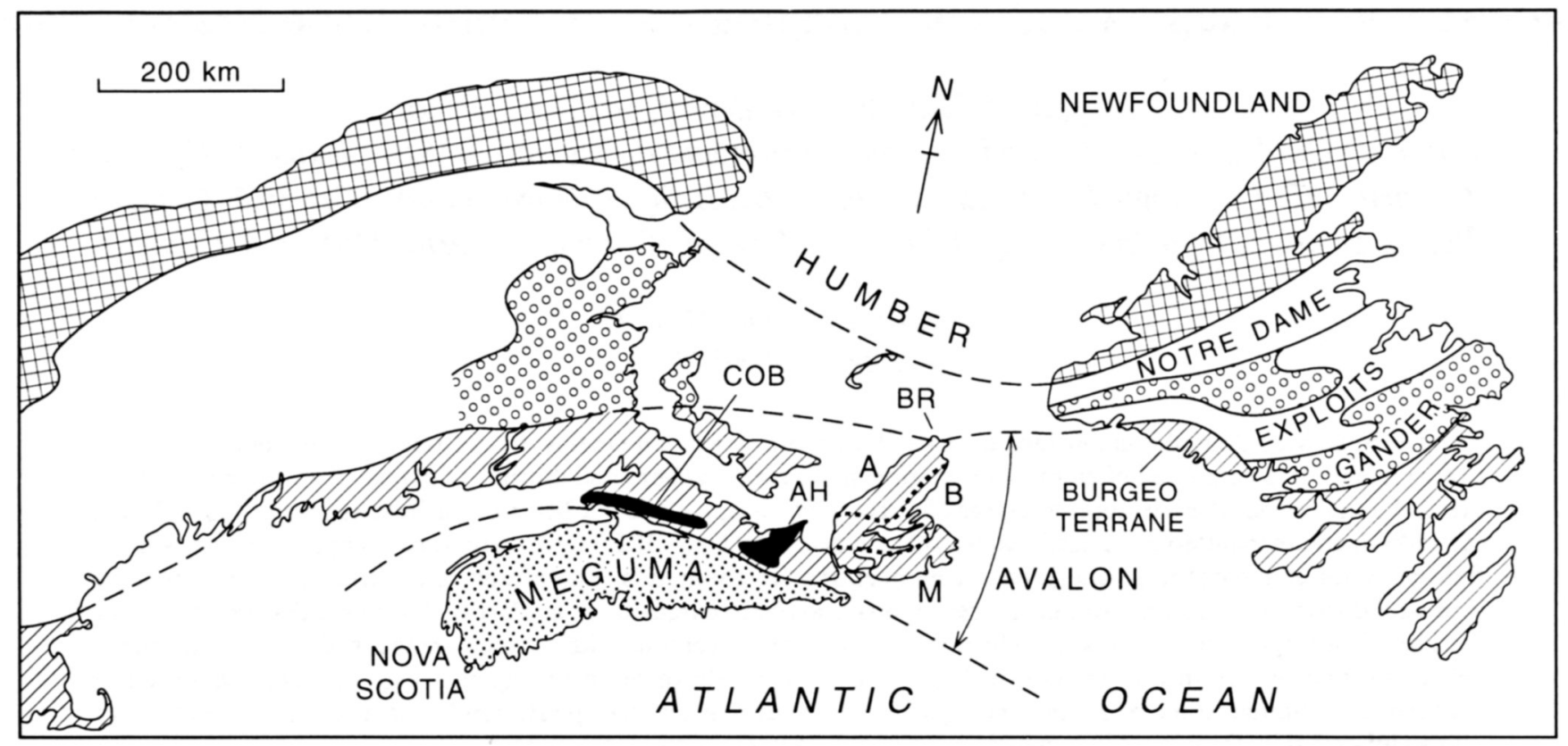

Fig. 1. Terrane map of the northern Appalachians modified from Keppie et al. (1998). Humber: cross hatched; Notre Dame and Exploits: blank; Gander: circles; Avalon: diagonal lines; Meguma: dotted. (M = Mira Terrane; B = Bras d'Or Terrane; A = Aspy Terrane; BR = Blair River Terrane; $\mathrm{AH}=$ Antigonish Highlands; $\mathrm{COB}=$ Cobequid Highlands. $)$

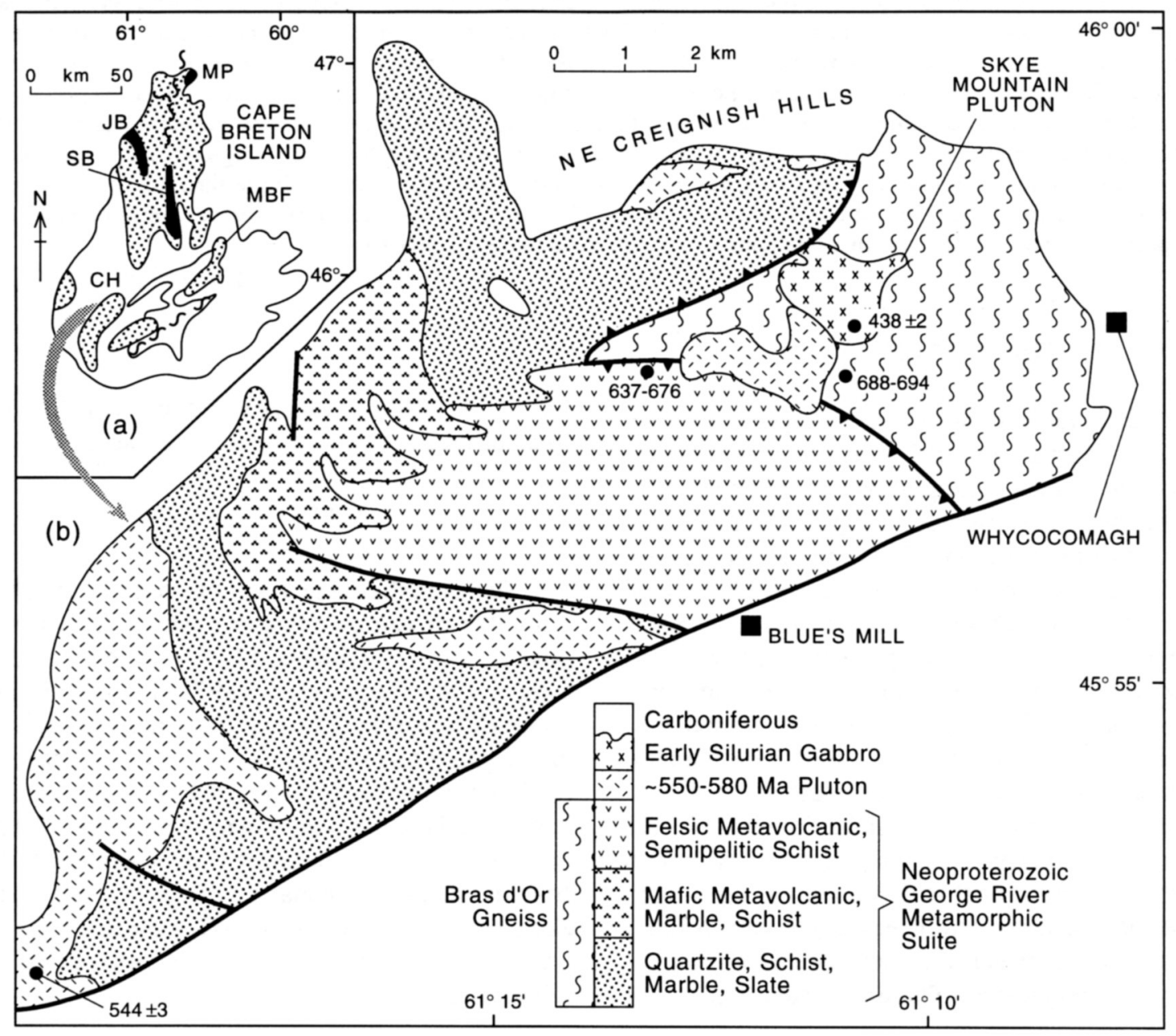

Fig. 2. (a) Map of Cape Breton Island showing highland areas (dotted) and Early Silurian volcanic rocks (black: MP = Money Point Group; JB = Jumping Brook Metamorphic Suite; SB = Sarach Brook Metamorphic Suite; $\mathrm{CH}=$ Creignish Hills; $\mathrm{MBF}=\mathrm{McMillan}$ Brook Fault) (b) Geological map of the Creignish Hills showing selected age dates (after Keppie et al., 1998). 
The Skye Mountain pluton is roughly circular about 1.5 km in diameter (Fig. 2b), and intruded the high-grade Late Proterozoic Bras d'Or Gneiss at the northeastern end of the Creignish Hills. Exposure is limited to a north-south river section and a few isolated outcrops. The pluton is undeformed and cuts across the structural fabrics in the gneisses. In southern Cape Breton Island, the Bras d'Or Gneiss is unconformably overlain by Cambrian-Ordovician rocks typical of the Avalon overstep sequence (Keppie, 1989; White et al., 1994). Volcanogenic gneiss just south of the pluton has yielded nearly concordant $\mathrm{U}-\mathrm{Pb}$ zircon ages between $688 \pm 3$ and $694 \pm 1 \mathrm{Ma}$ (Keppie et al., 1998), whereas from the same location ${ }^{40} \mathrm{Ar} /$ ${ }^{39} \mathrm{Ar}$ muscovite from gneiss gave a plateau age of $449 \pm 7 \mathrm{Ma}$, and from a pegmatite yielded a discordant spectrum that decreases from $\sim 485$ to $450 \mathrm{Ma}$ (Dallmeyer and Keppie, 1993).

\section{Petrography}

The Skye Mountain pluton is composed of mafic rocks which pass locally into quartz diorite along its northern part. The mafic rocks have colour indices typically ranging between 45 and 30, whereas the quartz diorites have indices between 30 and 20 . The mafic rocks are medium- to coarse-grained, hypidiomorphic but commonly non-equigranular. The gabbro-diorite is composed of plagioclase, amphibole and minor biotite with accessory zircon, sphene, apatite, ilmenite, magnetite, pyrite and hematite; epidote and calcite generally occur as fine veinlets. The quartz diorites differ in having a higher content of plagioclase, a minor amount of quartz and a higher proportion of biotite relative to amphibole. The rocks were affected by low-grade metamorphism which saussuritized the plagioclase and converted amphibole and biotite to chlorite (Horton, 1994).

Plagioclase, the most abundant phase in both lithologies, forms crystals typically about $1 \mathrm{~mm}$ in size, although locally it reaches up to $5 \mathrm{~mm}$. Although plagioclase is generally altered, the complex oscillatory zoning is still discernable.
The composition of the unaltered grains ranges between $\mathrm{An}_{32}$ and $\mathrm{An}_{58}$. Amphibole is the dominant ferromagnesian phase occurring as stumpy prismatic subhedral crystals. All are calcic amphiboles and according to the classification of Leake (1978) correspond to magnesio-hornblende. Biotite $(<10 \%)$ is Ti-rich (typically 3.5-4\% $\mathrm{TiO}_{2}$ ) with $\mathrm{X}_{\mathrm{Mg}_{\mathrm{g}}}$ ranging from 0.45 to 0.55 (Horton, 1994). Quartz is generally anhedral in shape and exhibits undulose extinction. Apatite, zircon, magnetite, and ilmenite represent the magmatic accessory phase assemblage in the pluton. Apatite and zircon are typically enclosed or in contact with ferromagnesian minerals. Opaque phases include magnetite, ilmenite and pyrite which generally occur adjacent to hornblende and biotite. Although most epidote is secondary, some epidote might be a primary phase as it is commonly enclosed within hornblende and biotite and is generally subhedral.

\section{ANALYTICAL TEChNiQues}

Zircon was separated from a $20 \mathrm{~kg}$ crushed sample and analyzed using standard procedures at the Royal Ontario Museum (Krogh and Keppie, 1990). Results are given in Table 1 and plotted on Figure 3. Errors in Table 1 are given at 1 sigma, whereas error ellipses in the figure are plotted at 2 sigma. Regressions are calculated using the program of Davis (1982) and the age errors are quoted at $95 \%$ confidence levels.

The major and several trace element $(\mathrm{Rb}, \mathrm{Ba}, \mathrm{Sr}, \mathrm{Y}, \mathrm{Zr}, \mathrm{Nb}$, $\mathrm{Ga}, \mathrm{Pb}, \mathrm{Zn}, \mathrm{Cr}$ and $\mathrm{Ni}$ ) analyses of twenty samples (detailed locations available from the authors) were determined by X-ray fluorescence at the Regional Geochemical Centre, Saint Mary's University, using a Philips PW1400 spectrometer. Reproducibility of the trace elements is about 1 to $5 \%$ (Dostal et al., 1986). In addition, eight samples were analyzed for rare-earth elements (REE), Th and Hf by ICP-MS at the Department of Earth Sciences of Memorial University of Newfoundland. Reproducibility is estimated to be better than $5 \%$.

Table 1. U-Pb isotopic data on abraded zircon fractions from the Skye Mountain pluton.

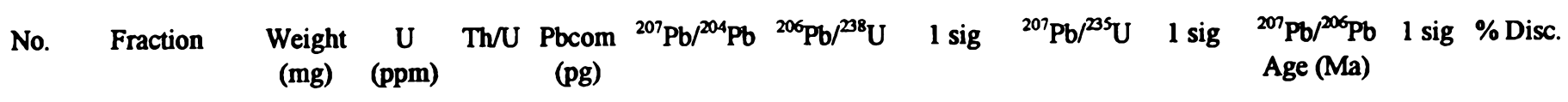

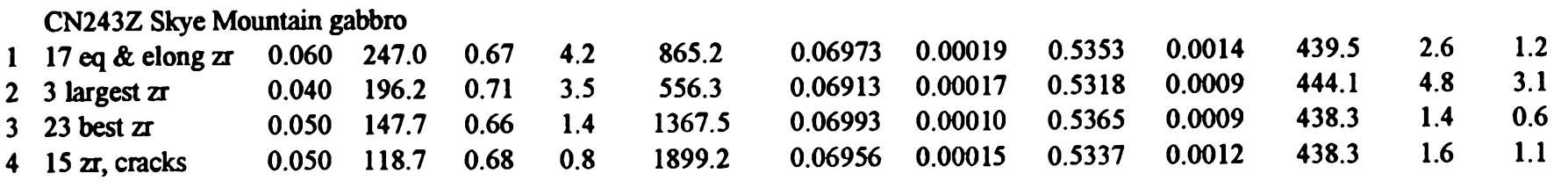

Errors are given at 1 sigma.

zx - zircon grain; eq - equant; elong - elongate.

Pbcom - Common $\mathrm{Pb}$, assuming all has blank isotopic composition.

$\mathrm{Th} / \mathrm{U}$ calculated from radiogenic ${ }^{208} \mathrm{~Pb} /{ }^{206} \mathrm{~Pb}$ ratio and ${ }^{207} \mathrm{~Pb} /{ }^{206} \mathrm{~Pb}$ age assuming concordance.

$\%$ Disc. - percent discordance for the given ${ }^{201} \mathrm{~Pb} /{ }^{206} \mathrm{~Pb}$ age.

Decay constants are from Jaffey et al. (1971). 


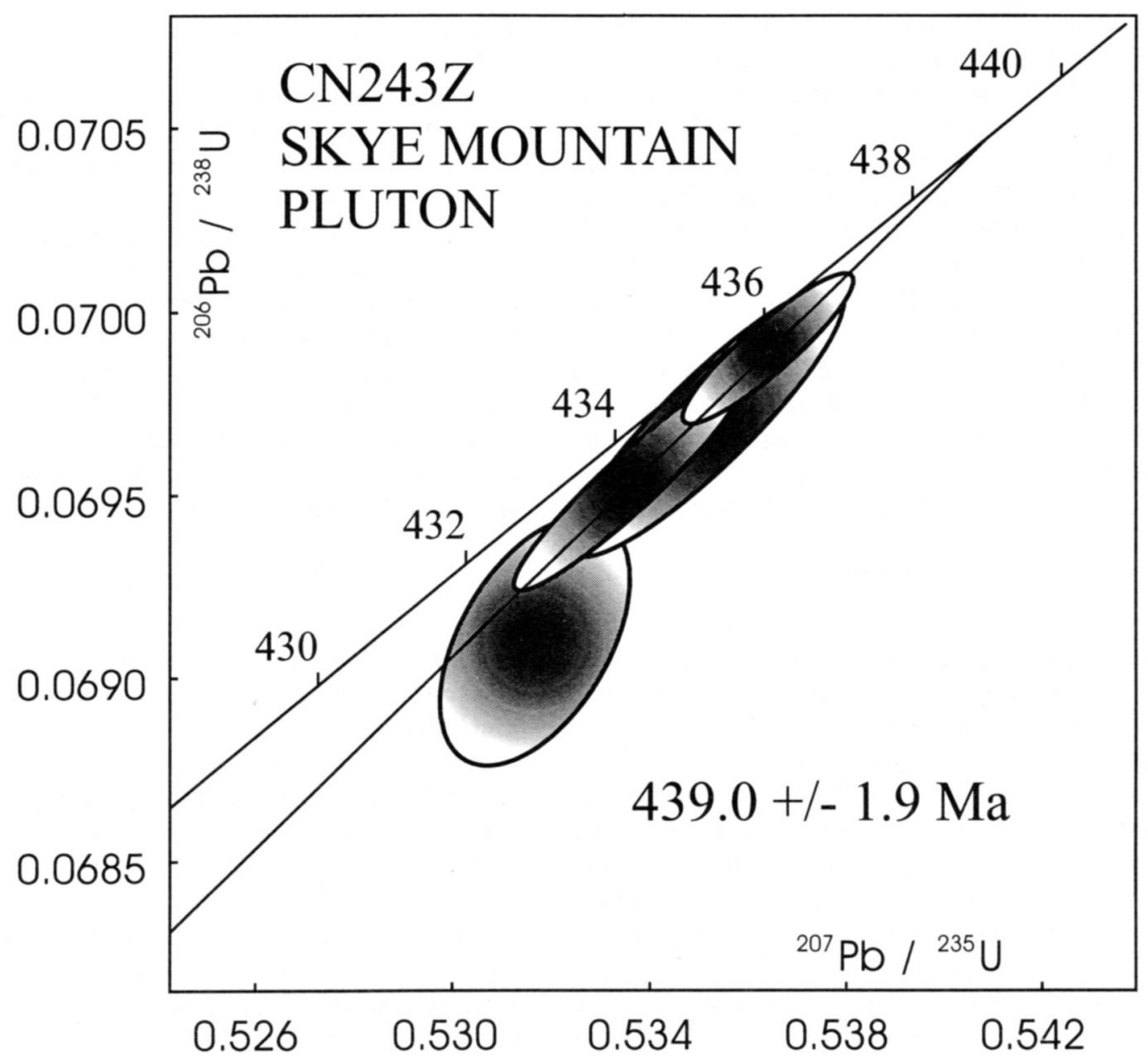

Fig. 3. Concordia plot of the U-Pb isotopic data from the Skye Mountain pluton.

Age

Four zircon fractions were analyzed from the Skye Mountain pluton (Fig. 3, Table 1), three of which are nearly concordant and define an average ${ }^{207} \mathrm{~Pb} /{ }^{20} \mathrm{~Pb}$ age of $439.0 \pm 1.9 \mathrm{Ma}$ (91\% probability of fit). The oldest ${ }^{206} \mathrm{~Pb} /{ }^{238} \mathrm{U}$ age is $436 \pm 1$ $\mathrm{Ma}$, which provides a younger limit on the time of crystallization. Thus, the crystallization age is $438 \pm 2 \mathrm{Ma}$. Using the Time Scale of Okulitch (1995), this age falls in the Llandoverian Epoch near the Silurian-Ordovician boundary at $441 \pm 2 \mathrm{Ma}$. The southern edge of the Skye Mountain pluton is $\sim 1 \mathrm{~km}$ from the dated muscovite samples (Dallmeyer and Keppie, 1993), which may explain their anomalously young ages.

\section{GeOCHEMISTRY}

Although the rocks were affected by secondary processes including low-grade metamorphism, it appears that the abundances of most major and trace elements were not significantly modified and retain their magmatic distribution. The rocks have a range of silica contents from 49 to $59 \%$ (Table 2, Fig. 4), with most samples falling within a narrow interval of 50 to $56 \%$ (LOI-free).
The mafic rocks of the pluton display subalkaline characteristics (Fig. 4) and are calc-alkaline (Fig. 5). Their chondrite-normalized REE concentrations (Fig. 6) have similar, moderately fractionated patterns $\left[(\mathrm{La} / \mathrm{Yb})_{n}=3-6\right.$; mostly 3-5] and small but variable Eu anomalies. The samples with lower absolute concentrations of REE display small positive Eu anomalies, whereas the sample with the highest REE contents has a small negative Eu anomaly. These variations are consistent with crystallization and accumulation of the major mineral phases present in the rocks: hornblende and plagioclase. Several rocks, such as sample 249 , were affected by an accumulation of hornblende as reflected by their REE patterns (Fig. 6).

The mantle-normalized profiles are also similar (Fig. 7) displaying pronounced negative $\mathrm{Nb}$ and other high-field-strength elements (HFSE, including $\mathrm{Ti}, \mathrm{Zr}$ and $\mathrm{Hf}$ ) anomalies and an enrichment in large-ion-lithophile elements (LILE, e.g., Rb, Th, light REE) that results in high LILE/HFSE ratios. These trace element characteristics are typical of arc magmatism. Several studies have shown plutonic and volcanic rocks of the same magmatic arc to be identical in composition (Saunders et al., 1980; McCulloch and Perfit, 1981). The mantle-normalized patterns of the Skye Mountain rocks are closely comparable to the range of the calc-alkaline andesites from the central volcanic zone of the Andes, South America (Thorpe et al., 
Table 2. Major and trace element compositions of samples from the Skye Mountain pluton.

\begin{tabular}{|c|c|c|c|c|c|c|c|c|c|}
\hline Sample & 243 & 247 & 248 & 249 & 250 & 253 & $253 \mathrm{~A}$ & 273 & 335 \\
\hline $\mathrm{SiO}_{2}(\%)$ & 53.02 & 48.43 & 53.85 & 49.80 & 53.96 & 52.17 & 53.73 & 56.30 & 49.53 \\
\hline $\mathrm{TiO}_{2}$ & 0.95 & 1.09 & 0.73 & 1.16 & 0.70 & 0.88 & 0.92 & 0.66 & 0.93 \\
\hline $\mathrm{Al}_{2} \mathrm{O}_{3}$ & 18.40 & 20.23 & 16.95 & 18.40 & 16.36 & 19.11 & 17.04 & 15.61 & 20.42 \\
\hline $\mathrm{Fe}_{2} \mathrm{O}_{3}{ }^{*}$ & 8.63 & 9.44 & 6.98 & 9.37 & 7.96 & 9.19 & 8.70 & 7.70 & 8.35 \\
\hline MnO & 0.17 & 0.20 & 0.26 & 0.14 & 0.14 & 0.12 & 0.16 & 0.13 & 0.27 \\
\hline MgO & 4.99 & 5.11 & 6.70 & 5.61 & 6.34 & 4.09 & 5.64 & 7.13 & 4.89 \\
\hline $\mathrm{CaO}$ & 6.31 & 7.61 & 4.30 & 6.82 & 6.52 & 7.74 & 6.96 & 6.64 & 5.71 \\
\hline $\mathrm{Na}_{2} \mathrm{O}$ & 3.32 & 3.27 & 3.62 & 3.44 & 3.07 & 3.19 & 3.14 & 2.69 & 4.78 \\
\hline $\mathrm{K}_{2} \mathrm{O}$ & 1.56 & 1.59 & 2.88 & 2.38 & 1.96 & 1.75 & 1.60 & 1.43 & 1.27 \\
\hline $\mathrm{P}_{2} \mathrm{O}_{5}$ & 0.33 & 0.20 & 0.14 & 0.30 & 0.09 & 0.27 & 0.16 & 0.10 & 0.20 \\
\hline LOI & 1.90 & 2.10 & 2.80 & 2.70 & 2.10 & 1.70 & 1.80 & 1.90 & 3.80 \\
\hline$\Sigma$ & 99.58 & 99.27 & 99.21 & 99.21 & 99.20 & 100.21 & 99.85 & 100.29 & 100.15 \\
\hline Mg\# & 0.53 & 0.52 & 0.66 & 0.54 & 0.61 & 0.47 & 0.56 & 0.65 & 0.54 \\
\hline $\mathrm{Cr}$ (ppm) & 69 & 44 & 281 & 82 & 261 & 16 & 81 & 318 & 93 \\
\hline $\mathrm{Ni}$ & 49 & 44 & 114 & 63 & 78 & 21 & 56 & 119 & 55 \\
\hline V & 241 & 318 & 147 & 267 & 248 & 246 & 252 & 195 & 234 \\
\hline $\mathrm{Cu}$ & 41 & 95 & & 77 & 40 & 29 & 54 & 49 & 9 \\
\hline $\mathrm{Pb}$ & 44 & 49 & 80 & & & 13 & 34 & & 12 \\
\hline $\mathrm{Zn}$ & 122 & 186 & 262 & 88 & 93 & 74 & 85 & 77 & 405 \\
\hline $\mathrm{Rb}$ & 69 & 69 & 107 & 107 & 88 & 69 & 63 & 54 & 73 \\
\hline $\mathrm{Ba}$ & 241 & 229 & 306 & 371 & 316 & 225 & 271 & 272 & 187 \\
\hline $\mathrm{Sr}$ & 464 & 514 & 418 & 467 & 396 & 472 & 379 & 325 & 563 \\
\hline Ga & 21 & 23 & 16 & 21 & 19 & 19 & 20 & 16 & 20 \\
\hline $\mathrm{Nb}$ & 5.0 & 3.5 & 4.3 & 7.7 & 3.5 & 4.9 & 5.5 & 4.8 & 3.3 \\
\hline Hf & 2.70 & 1.54 & 2.58 & 3.31 & 2.81 & 2.18 & 2.28 & 2.92 & 1.27 \\
\hline $\mathrm{Zr}$ & 94 & 56 & 98 & 111 & 105 & 78 & 68 & 114 & 43 \\
\hline Y & 18 & 14 & 17 & 36 & 18 & 20 & 22 & 23 & 13 \\
\hline Th & 4.06 & 2.25 & 4.72 & 2.94 & 4.85 & 3.34 & 4.24 & 4.23 & 1.75 \\
\hline $\mathrm{La}$ & 16.42 & 10.54 & 13.32 & 18.75 & 13.08 & 15.76 & 13.40 & 14.24 & 10.02 \\
\hline $\mathrm{Ce}$ & 37.93 & 24.37 & 29.74 & 51.24 & 29.03 & 34.98 & 31.82 & 28.52 & 22.28 \\
\hline Pr & 4.84 & 3.11 & 3.74 & 7.45 & 3.67 & 4.39 & 4.23 & 3.88 & 2.83 \\
\hline Nd & 20.04 & 13.91 & 15.88 & 34.23 & 15.40 & 17.85 & 18.08 & 16.32 & 12.34 \\
\hline $\mathrm{Sm}$ & 4.29 & 2.97 & 3.63 & 8.04 & 3.74 & 4.22 & 4.50 & 4.15 & 2.77 \\
\hline $\mathrm{Eu}$ & 1.31 & 1.10 & 1.05 & 1.74 & 1.05 & 1.25 & 1.16 & 1.06 & 1.13 \\
\hline Gd & 4.17 & 3.00 & 3.78 & 7.84 & 3.55 & 4.20 & 4.54 & 4.06 & 2.69 \\
\hline $\mathrm{Tb}$ & 0.61 & 0.43 & 0.55 & 1.21 & 0.56 & 0.66 & 0.70 & 0.68 & 0.42 \\
\hline Dy & 3.53 & 2.61 & 3.25 & 7.04 & 3.37 & 3.99 & 4.38 & 4.12 & 2.49 \\
\hline Ho & 0.72 & 0.54 & 0.67 & 1.40 & 0.69 & 0.80 & 0.89 & 0.86 & 0.50 \\
\hline $\mathrm{Er}$ & 2.01 & 1.45 & 1.99 & 3.94 & 1.97 & 2.22 & 2.54 & 2.51 & 1.52 \\
\hline $\mathrm{Tm}$ & 0.27 & 0.21 & 0.27 & 0.56 & 0.29 & 0.30 & 0.35 & 0.36 & 0.22 \\
\hline Yb & 1.82 & 1.33 & 1.89 & 3.46 & 1.87 & 2.01 & 2.38 & 2.40 & 1.37 \\
\hline Lu & 0.27 & 0.21 & 0.27 & 0.51 & 0.29 & 0.30 & 0.34 & 0.36 & 0.22 \\
\hline
\end{tabular}

$M g \#=M g /\left(M g+F e_{(0)}\right)$.

1984) and Hercynian quartz diorites from the French Massif Central (Shaw et al., 1993). The strong enrichment of LILE in mafic rocks is indicative of emplacement into a continental crust. Compared to oceanic equivalents, a distinct enrichment of LILE in continental calc-alkaline magmas is usually considered to result from either the presence of enriched mantle source beneath continental margins (Saunders et al., 1980) or to "MASH" (melting, assimilation, storage, homogenization) processes (Hildreth and Moorbath, 1988). 


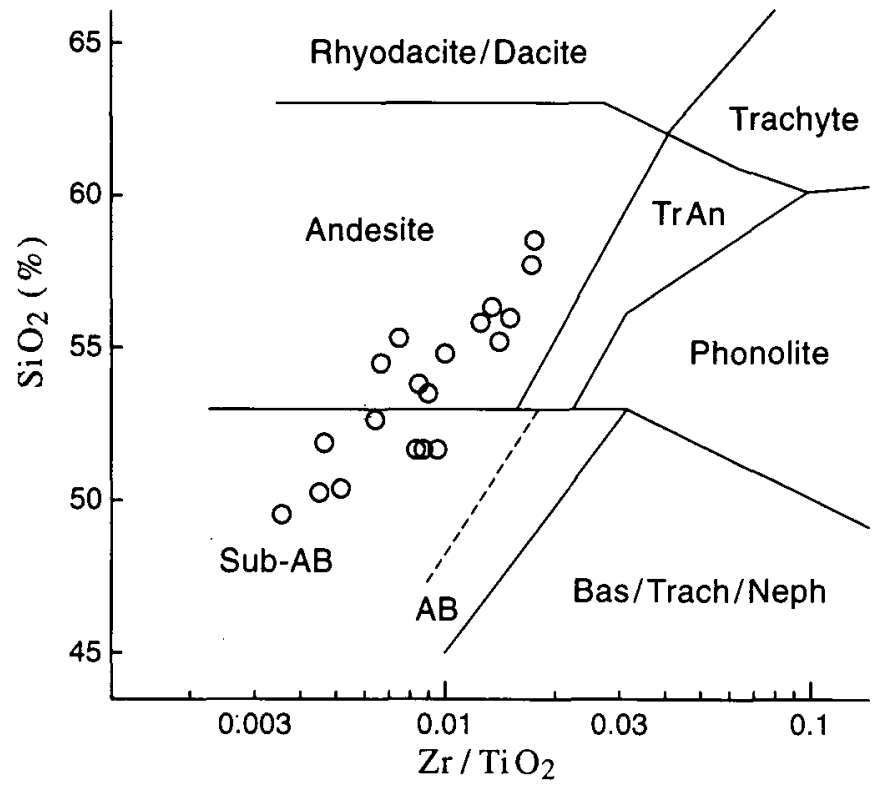

Fig. 4. $\mathrm{Zr} / \mathrm{TiO}_{2}$ versus $\mathrm{SiO}_{2}(\%)$ diagram of Winchester and Floyd (1977) for the rocks of the Skye Mountain pluton. $A B=$ alkali basalts; Sub-AB = subalkaline basalts; $\operatorname{Tr} A n$ = trachyandesites; $\mathrm{Bas} / \mathrm{Trach} / \mathrm{Neph}=$ basalt/trachyte/nephelinite.

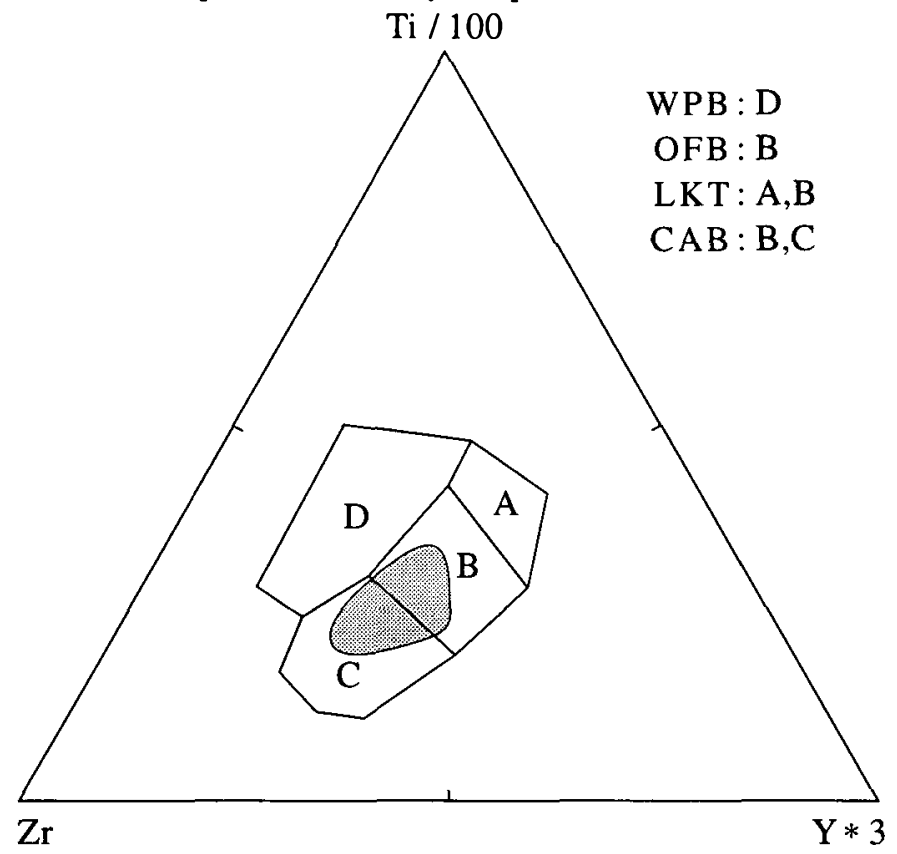

Fig. 5. Zr-Y-Ti discrimination diagram of Pearce and Cann (1973) for the mafic rocks of the Skye Mountain pluton. Cumulate rocks were not plotted. Fields: $A=$ island arc tholeites and ocean floor basalts; $B=$ ocean floor basalts and calc-alkaline basalts; $C=$ calcalkaline basalts; $\mathrm{D}=$ within-plate basalts

\section{TeCtonic IMPLiCations}

The geochemistry of the Skye Mountain pluton compares most closely with the following similar calc-alkaline volcanic rocks in the Cape Breton Highlands (Macdonald and Smith, 1980; Barr and Jamieson, 1991) and southern Newfoundland: (1) Sarach Brook metamorphic suite in the southem Cape Breton Highlands includes rhyolites which have been dated at 434 +7/-4 Ma (U-Pb zircon age: Dunning et al., 1990a); (2) Jump-

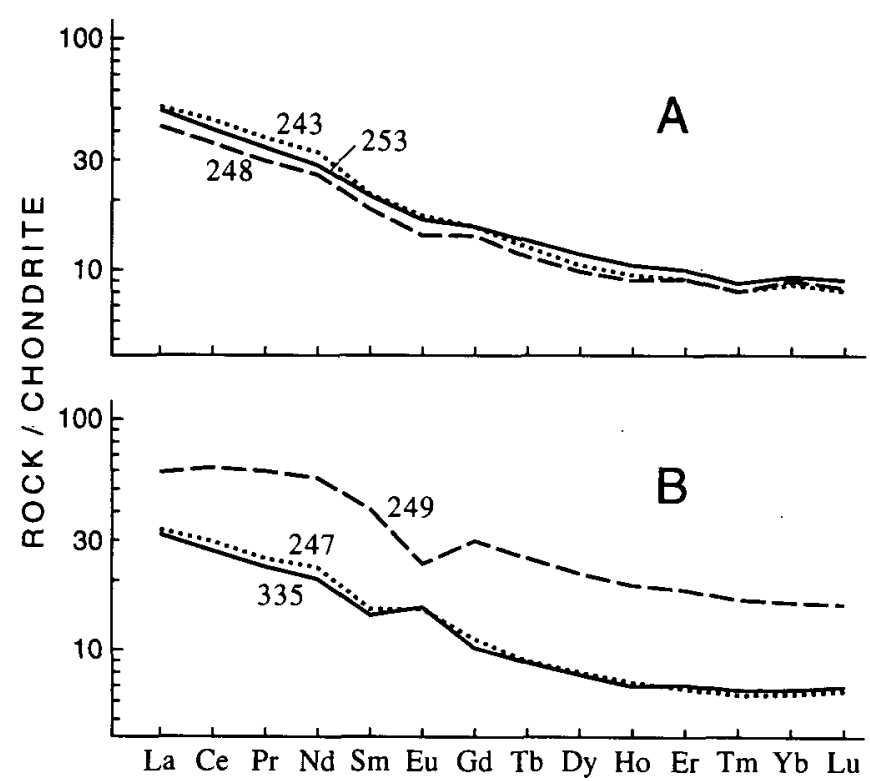

Fig. 6. Chondrite-normalized rare-earth element abundances of the rocks from the Skye Mountain pluton. $A=$ non-cumulate plutonic rocks; B = cumulate plutonic rocks (249 - hornblende cumulate; 247 and 335 - plagioclase cumulate). Normalizing values after Sun (1982).

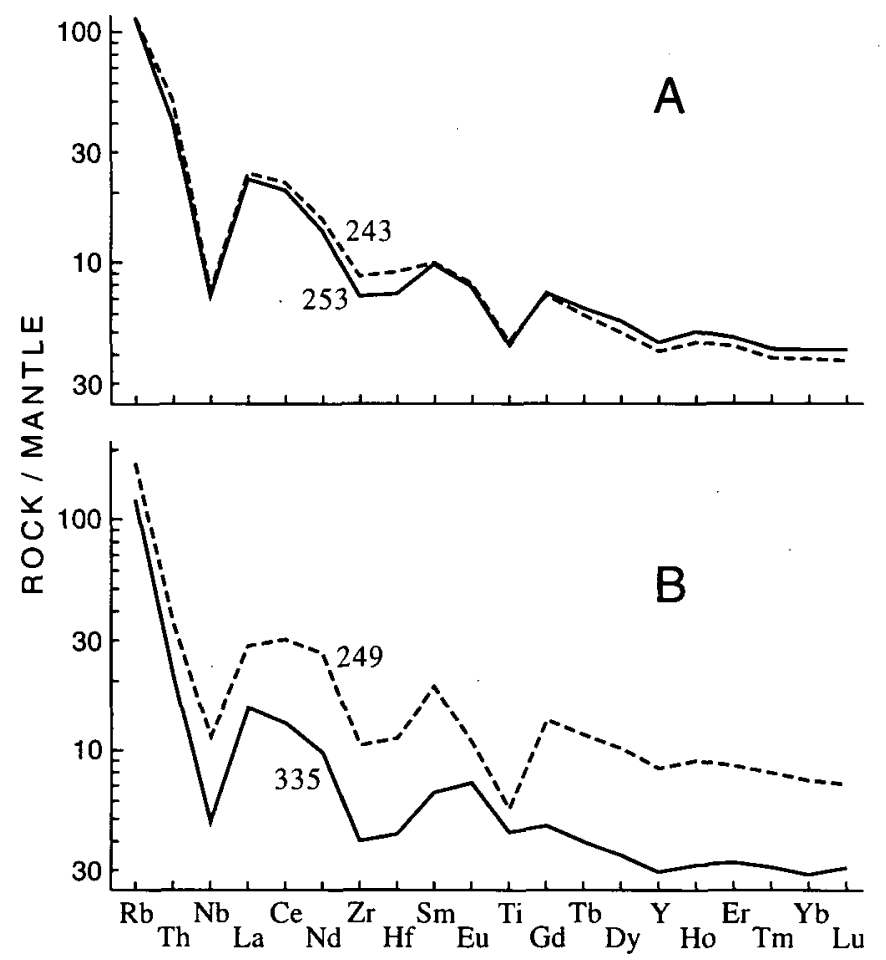

Fig. 7. Primitive mantle-normalized abundances of trace elements in the rocks from the Skye Mountain pluton. $A=$ non-cumulate plutonic rocks; B = cumulate plutonic rocks (249 - hornblende cumulate; 335 - plagioclase cumulate). Normalizing values after Sun and McDonough (1989).

ing Brook metamorphic suite in the western Cape Breton Highlands for which a feeder dyke yielded an age of $439 \pm 7 \mathrm{Ma}$ (U-Pb zircon age: Currie et al., 1982); (3) Money Point Group in northern Cape Breton Island gave an age of $428 \pm 4 \mathrm{Ma}$ 
(U-Pb zircon age: Keppie et al., 1992); and (4) La Poile Group in the Burgeo Terrane of southern Newfoundland yielded ages ranging from $428 \pm 6 \mathrm{Ma}$ to $420+8 /-2 \mathrm{Ma}$ (Dunning et al., $1990 \mathrm{~b})$. The calc-alkaline nature of these volcanic rocks is interpreted as a supra-subduction zone magmatic arc, which extended as far south as central Cape Breton Island. The rapid burial of these rocks to $25 \mathrm{~km}$ by ca. $415 \mathrm{Ma}$ (Keppie et al., 1992) has been interpreted in terms of an intra-arc rifting above an oblique subduction zone, similar to that in the present-day arc of Central America (Burkart and Self, 1985). Associated rifting may also explain the earliest Silurian tholeiitic magmatism in the Antigonish Highlands (Fig. 7; Keppie et al., 1997).

Chandler et al. (1987) have suggested that Lower Silurian rocks represent an overstep sequence between Laurentia and the Avalon, a proposition supported by the first appearance of Laurentian Nd signatures in the Avalon during the earliest Silurian (Murphy et al., 1996). However, the occurrence of calc-alkaline magmatism through the Llandovery and Wenlock in the Cape Breton Highlands and southern Newfoundland suggests that Iapetus was not completely closed until the Late Silurian. These observations may be reconciled if only small ocean basins remained in the Early Silurian and convergence was mainly orogen-parallel (Fig. 8).

\section{ACKNOWLEDGEMENTS}

Funds for this project were supplied by the Canada-Nova Scotia Mineral Development Agreement and NSERC of Canada. We are grateful to $\mathrm{L}$. Fyffe and an anonymous reviewer for their constructive reviews of the manuscript.

BARR, S.M. and JAmieson, R.A. 1991. Tectonic setting and regional correlation of Ordovician-Silurian rocks of the Aspy Terrane, Cape Breton Island, Nova Scotia. Canadian Journal of Earth Sciences, 28, pp. 1769-1779.

Burkart, B. and Self, S. 1985. Extension and rotation of crustal blocks in northern Central America and effect on the volcanic arc. Geology, 13, pp. 22-26.

Chandler, F.W., Loveridge, D., and Currie, K.L. 1987. The age of the Springdale Group, western Newfoundland, and cor- relatives rocks - evidence for a Llandovery overlap sequence in the Canadian Appalachians. Transactions of the Royal Society of Edinburgin, 78, pp. 41-49.

Currie, K.L., Loveridge, W.D., and Sullivan, R.W. 1982. A U-Pb age on zircon from dykes feeding basal rhyolite flows of the Jumping Brook complex, northwestern Cape Breton Island, Nova Scotia. Geological Survey of Canada, Paper 79-1C, pp. 125-128.

Dallmeyer, R.D. and Keppie, J.D. 1993. ${ }^{40} \mathrm{Ar} /{ }^{39} \mathrm{Ar}$ mineral ages from southern Cape Breton Highlands and Creignish Hills, Nova Scotia, Canada: evidence for a polyphase tectonothermal evolution. Journal of Geology, 101, pp. 467-482.

DAvis, D. 1982. Optimum linear regression and error estimation applied to U-Pb data. Canadian Journal of Earth Sciences, 19, pp. 2141-2149.

Dostal, J., Baragar, W.R.A., and Dupuy, C. 1986. Petrogenesis of the Natkusiak continental basalts, Victoria Island, N.W.T. Canadian Journal of Earth Sciences, 23, pp. 622-632.

Dunning, G.R., BARR, S.M., Raeside, R.P., and JAmieson, R.A. 1990a. U-Pb zircon, titanite, and monazite ages in the Bras d'Or and Aspy terranes of Cape Breton Island, Nova Scotia: implications for igneous and metamorphic history. Geological Society of America Bulletin, 102, pp. 322-330.

Dunning, G.R., O'Brien, S.J., Colemen-Sadd, S.P., et al. 1990b. Silurian Orogeny in the Newfoundland Appalachians. Journal of Geology, 98, pp. 895-913.

HiLDRETH, W. and MoORBath, S. 1988. Crustal contributions to arc magmatism in the Andes of Central Chile. Contributions to Mineralogy and Petrology, 98, pp. 455-489.

Horton, D.H. 1994. The geochemistry and petrology of the Skye Mountain pluton, Cape Breton Island, Nova Scotia. BSc. thesis, Saint Mary's University, 103 p.

Jaffey, A.H., FlynN, K.F., Glendenin, L.E., Bentley, W.C., and Essuing, A.M. 1971. Precision measurement of half-lives and specific activities of ${ }^{235} \mathrm{U}$ and ${ }^{238} \mathrm{U}$. Physical Review, 4, pp. 1889-1906.

KePpie, J.D. 1985. The Appalachian Collage. In The Caledonide Orogen: Scandinavia and related areas. Edited by D.G. Gee and B.A. Sturt. J. Wyllie and Sons, New York, pp. 1217-1226.

1989. Northern Appalachian terranes and their accretionary history. Geological Society of America, Special Paper 230, pp. 159-192.

Keppie, J.D., Dostal, J., and Zentilli, M. 1979. Early Silurian volcanic rocks at Arisaig, Nova Scotia. Canadian Journal of Earth Sciences, 16, pp. 1635-1639.

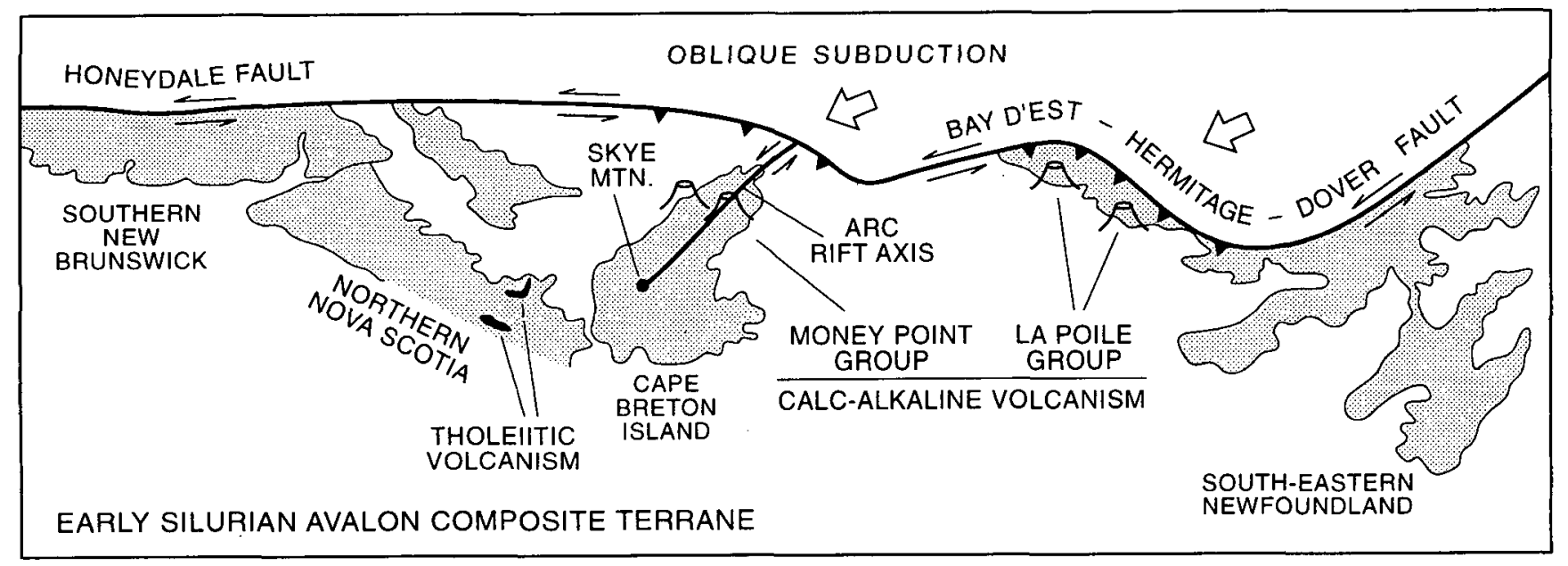

Fig. 8. Early Silurian tectonic model for the Avalon Composite Terrane (modified from Keppie et al., 1992; Whalen et al., 1996: see text for other references). 
KePPIE, J.D., Dallmeyer, R.D., and KROGH, T.E. 1992. U-Pb and ${ }^{40} \mathrm{Ar} /{ }^{39} \mathrm{Ar}$ mineral ages from Cape North, northern Cape Breton Island: implications for accretion of the Avalon Composite Terrane. Canadian Journal of Earth Sciences, 29, pp. 277-295.

Keppie, J.D., Dostal, J., Murphy, J.B., and Cousens, B.L. 1997. Paleozoic within-plate volcanic rocks in Nova Scotia (Canada) reinterpreted: isotopic constraints on magmatic source and paleocontinental reconstructions. Geological Magazine, 134, pp. $425-447$.

KepPIE, J.D., Davis, D.W., and KROGh, T.E. 1998. U-Pb geochronological constraints on Precambrian stratified units in the Avalon Composite Terrane of Nova Scotia, Canada: tectonic implications. Canadian Journal of Earth Sciences, 35, pp. 222-236.

KROGH, T.E. and KePPIE, J.D. 1990. Age of detrital zircon and titanite in the Meguma Group, southern Nova Scotia, Canada: clues for the origin of the Meguma Terrane. Tectonophysics, 177, pp. 307-323.

LEAKE, B.E. 1978. Nomenclature of amphiboles. Mineralogical Magazine, 42, pp. 553-563.

Macdonald, A.S. and Smith, P.K. 1980. Geology of the Cape North area, northern Cape Breton Island, Nova Scotia. Nova Scotia Department of Mines and Energy, Paper 80-1, 60 p.

McCulloch, M.T. and Perfit, M.R. $1981 .{ }^{143} \mathrm{Nd} /{ }^{144} \mathrm{Nd},{ }^{87} \mathrm{Sr} /{ }^{86} \mathrm{Sr}$ and trace element constraints on the petrogenesis of Aleutian island arc magmas. Earth and Planetary Science Letters, 56, pp. 167-179.

Murphy, J.B., Keppie, J.D., Dostal, J., Waldron, J.F.W., and Cude, M.P. 1996. Geochemical and isotopic characteristics of Early Silurian clastic sequences in Antigonish Highlands, Nova Scotia, Canada: constraints on the accretion of Avalonia in the Appalachian-Caledonide Orogen. Canadian Journal of Earth Sciences, 33, pp. 379-388.

Окицiтсн, A.V. 1995. Geological Time Chart. Geological Survey of Canada, Open File 3040.

Pearce, J.A. and CANn, J.R. 1973. Tectonic setting of basic volcanic rocks determined using trace element analyses. Earth and Planetary Science Letters, 19, pp. 290-300.

Saunders, A.D., Tarney, J., and Weaver, S.D. 1980. Transverse geochemical variations across the Antarctic Peninsula: impli- cation for the genesis of calc-alkaline magmas. Earth and Planetary Science Letters, 46, pp. 344-360.

Shaw, A., Downes, H., and Thirlwall, M.F. 1993. The quartz-diorites of Limousin: Elemental and isotopic evidence for Devono-Carboniferous subduction in the Hercynian belt of the French massif Central. Chemical Geology, 107, pp. 1-18.

Sun, S.S. 1982. Chemical composition and origin of the Earth's primitive mantle. Geochimica et Cosmochimica Acta, 46, pp. 179-192.

Sun, S.S. and McDonough, W.F. 1989. Chemical and isotopic systematics of oceanic basalts: implications for mantle composition and processes. In Magmatism in the Ocean Basins. Edited by A.D. Saunders and M.J. Norry. Geological Society of London, Special Publication 42, pp. 313-345.

ThORPE, R.S., Francis, P.W., and O'Callaghan, L. 1984. Relative roles of source composition, fractional crystallization and crustal contamination in the petrogenesis of Andean volcanic rocks. Philos. Transactions of the Royal Society of London, Ser. A. 310, pp. 675-692.

Whalen, J.B., Fyffe, L.R., Longstaffe, F.J., and Jenner, G.A. 1996. The position and nature of the Gander-Avalon boundary, southern New Brunswick, based on geochemical and isotopic data from granitoid rocks. Canadian Journal of Earth Sciences, 33, pp. 129-139.

White, C.E., Barr, S.M., Bevier, M.L., and Kamo, S. 1994. A revised interpretation of Cambrian and Ordovician rocks in the Bourinot belt of central Cape Breton Island, Nova Scotia. Atlantic Geology, 30, pp. 123-142.

Williams, H. 1978. Tectonic lithofacies map of the Appalachian Orogen. Memorial University of Newfoundland, Map No. 1, Scale 1:1,000,000.

Williams, H. and Hatcher, R.D. 1982. Suspect terranes and accretionary history of the Appalachian Orogen. Geology, 10, pp. 530-536.

WINCHESTER, J.A. and FLOYD, P.A. 1977. Geochemical discrimination of different magma series and their differentiation products using immobile elements. Chemical Geology, 20, pp. 325-343. 